\title{
Intellectual Scaffolding: On Peter Dahlgren's Theorization of Television and the Public Sphere
}

Minna Aslama

Fordham University, minna.aslama@helsinki.fi

Follow this and additional works at: https://fordham.bepress.com/mcgannon_working_papers

Part of the Communication Technology and New Media Commons

\section{Recommended Citation}

Aslama, Minna, "Intellectual Scaffolding: On Peter Dahlgren's Theorization of Television and the Public Sphere" (2006). McGannon Center Working Paper Series. 9.

https://fordham.bepress.com/mcgannon_working_papers/9 
T H E

DONALD M C G A N O N

COMMUNICA TION RESEARCH CENTER

WORKING PAPER

INTELLECTUA L SCAFFOLDING: ON PETER DA HLGREN'S THEORIZATION OF TELEVISION AND THE PUBLIC SPHERE

Minna As 1 a ma

Visiting Research Fellow

Donald McGannon Communication Research Center Swedish School of Social Science

University of Helsinki, Finland minna.aslama@helsinki.fi

A pri1, 2006

Donald McGannon Communication Research Center Faculty Memorial Hall, $4^{\text {th }} \mathrm{fl}$.

B ronx, N Y 10458

718.817 .4195

www.fordham.edu/mcgannon

mcgctr@fordham.edu

The author acknowledges the support of the Academy

of Finland and the Centennial Foundation of

Helsingin Sanomat which made possible the Visiting

Research Fellowship at the McGannon Center 


\begin{abstract}
In this working paper, my goal is to revisit Habermasian public sphere theory by first discussing its strengths and weaknesses in the context of today's (western European) television landscape. I then move on to exploring one reconceptualization of television as a public sphere, that of the Swedish scholar Peter Dablgren (1995 \& 2005). Finally, I elaborate and further develop those key aspects of Dablgren's model that I consider particularly relevant for rethinking the public sphere of today.
\end{abstract}

\title{
1. Public Sphere and Television Today
}

Television in its many senses - as a medium, an institution, an industry - has gone through fundamental changes in the past decade. These, in turn, have evoked numerous predictions and scenarios, from 'dumbing down' of television culture to the eventual 'death of television', inspired by the technology-oriented utopias of the Internet taking over as the key medium, and television merging with other forms of media. Still, TV remains as the most influential mass medium in Europe, alone if measured simply by the time people spend with it. In fact, there are great expectations for television as the key medium enhancing democracy and civic participation, expressed in the European Union policy statements as well as in national memoranda and reports on the topic.

Yet, for many media scholars as well as political scientists, Jürgen Habermas' theory of the public sphere may at the outset appear outdated when considering today's television landscapes in Europe or elsewhere. In his famous study The Structural Transformation of the Public Sphere (1989/1962), Habermas builds his model upon the development of the bourgeois society of the $17^{\text {th }}$ and $18^{\text {th }}$ century Europe. Based on that context, he suggests that a space was then formed and realised between the economy and polity where people could be informed and discuss, so as to form decisions and act upon them. The instruments of this sphere were newspapers, books, salons and debating societies that allowed an arena relatively separate of the Church and the State, characterised by openness to all citizens, in the sense of the $18^{\text {th }}$ century. As follows, he sees such a communicative forum as a model for a public sphere that facilitates rational-critical debate amongst citizens, that accordingly ensures political will formation, and that is therefore crucial for democracy. 
In contrast, the present context, with technological advances such as digitalisation, coupled with debates on globalisation as well as on cultural, economic and political neoliberal tendencies might point towards other approaches in understanding television's role in the society. To be sure, much of postmodern theorisation of popular culture in the 1990s would suggest alternative outlooks. Also, Habermas himself considered the public sphere already at the time of the publishing of his study to be 'refeudalised'. He viewed the mass media's role as a public sphere dubious, as they give in to commercial imperatives and address their viewers as consumers. His scepticism is illustrated by the following quotes:

\footnotetext{
"Mass culture has earned its rather dubious name precisely by achieving increased sales by adapting to the need for relaxation and entertainment on the part of consumer strata with relatively little education, rather than through the guidance of an enlarged public toward the appreciation of a culture undamaged in its substance." (Habermas 1962/1989, 165.)
}

"The world fashioned by the mass media is a public sphere in appearance only. By the same token the integrity of the private sphere which they promise to their consumers is also an illusion.” (Habermas 1962/1989, 171.)

Yet, as the above citations illustrate, his argumentation seems to share features with the public debate that surrounds at least European television today. These arguments address the concern for contents geared towards entertainment for commercial reasons, for the positioning of viewers as indulging consumers rather than rational-critical citizens, for the diminishing political participation and, as the end result of these tendencies, for the crisis of democracy.

The resonance and relevance of the Habermasian idea of the public sphere can also be said to manifest in the vast amount theorising and application it has inspired. Alone the amount of revising and criticism emphasises the importance of this thought. Different points of dissatisfaction include the claim that Habermas idealizes the bourgeois public sphere and its thrive for public enlightenment while neglecting other, 'plebeian' public spheres. It has also been said that he exaggerates the idea of 'refeudalisation' and the 
manipulative powers of culture industries in the mass media era. Yet another critique is that Habermas emphasises rational consensus rather than the continuing need for compromise of differing interests, and for a pluralist public sphere. Thus, it has been claimed, he dismisses communication that is not geared toward consensus and accordingly, creates too great of a boundary between information and entertainment.

Despite of the doubts presented about the public sphere idea, Habermas' work has influenced many disciplines and debates ranging from the democratic theory of political science, the self-reflection of cultural critics, the modernism/postmodernism debate, to empirical studies in sociology and communications. Specifically, as Peter Dahlgren (2005, 411-12) notes, the role of television has explicitly or implicitly been framed in the public sphere thematic also in countless recent analyses, whether they concern new genres such as those that fall under the term of reality television, whether they address globalisation of national television culture, or whether they seek to tackle the evolution of broadcasting journalism. The public sphere has proven useful both as an analytical concept but also as normative ideal - and, as Dahlgren (op cit.) points out, it has in the course of years left the strict Frankfurt School theory realm and is now often used more generically to refer to democratic goals and responsibilities of the media and the civic life.

It is in the spirit of the latter definition that Peter Dahlgren (2004) writes about the role of theory as 'intellectual scaffolding':

"[Theory] serves to orient us, to pull together sets of facts and assumptions, and offers normative dispositions. It helps to provide significance to what we observe, and to suggest the various types of action or intervention. In this sense, there may not always be demarcated distinctions between formalized theory and the more general (and less systematic) thought modes we use.” (Dahlgren 2004, 11.)

Still, in this paper I do not advocate on the notion of the public sphere solely as a vague set of expectations for the media in democratic societies, but wish to sharpen the idea with the help of existing criticism as well as specify it regarding television. The thematic 
of the public sphere, I argue, benefits from the various further theorizations and coupled with them, may further understanding of the phenomenon of television of the past decades as well as today. The main features of the Habermasian public sphere that call for revision today, are therefore discussed below.

\section{Normative Sphere Revisited}

First, in the most fundamental level, most critics seem to agree that Habermas' model is too normative as it celebrates the $18^{\text {th }}$ century liberal world. In the realm of theorisation on democracy, it could be interpreted that the existence of a public sphere in the $20^{\text {th }}$ century social-welfare mass democracy is virtually impossible. Habermas, then, sees little potential with today's mass media that are not only distorted by commercial imperatives to entertain, but that also reduce to a minimum the 'distance that required the privacy of appropriation as much as it made possible the publicity of a rational-critical exchange' $(1996,170)$.

Regardless, there is no question about the fundamental role that is given to the notion of the public sphere when defining the media's role in the society. In this context, radio and television - and beginning of the new millennium also new media such as the Internet cannot be dismissed. The electronic media have become undeniably and tightly connected with what is considered political, both in traditional institutional sense as well as an integral part what cultural studies oriented scholar call the politics of the everyday and politics of popular culture. Accordingly, it has been argued that the emphasis on the interpersonal communication as the normative basis for the public sphere must be reevaluated, and meanings of time and space for public communication have to be addressed. The discussion is given another twist by the cultural studies media theorists who address the media in the postmodern context. Thinkers of this tradition recognise and dismiss Habermas' normativity and see his work too deeply rooted in the modern Enlightment philosophies. (e.g., Preston 2001; Thompson 1995.) 
Linked to the above critique is another key notion embedded in the idea of the public sphere, namely the distinction or the opposition between the public and the private. This have been extensively theorised and debated within political and social sciences (e.g., discussion in Dahlgren 1995 and 2005). Alone the definitions of the public and the private are tricky: For example, John B. Thompson (1995, 121-123) distinguishes two different meanings for private and public domains which both bear relevance in discussions about the media. The first meaning refers to the private domain as consisting of organisations functioning in the market economy and the personal life and relations; and the public domain including state-owned economic and other organisations. In between exist, in his view, intermediate organisations such as political parties. On the other hand, Thompson sees another meaning in the concepts of the public and the private that deal their meanings as attributes (public, private): These are related to visibility and invisibility, publicness and privacy.

The latter meaning has been widely discussed in relation to the media, both by political scientists and cultural studies scholars in relation to the media, as it seems that the conventions regarding these attributes are rapidly and continuously changing (a summary account of the discussions is provided by, e.g., Dahlgren 2005, 419). Often used empirical examples are politicians' celebrity status and their private affairs making headlines in 'quality' as well as popular media; and the mirror phenomenon of 'ordinary people's' lives becoming public in talk shows and reality programmes. In most Western democracies, worried discussions have been carried out on the redefinitions of the public and the private, the fear being that the increasing interest in the private and the personal overshadows issues of more general social and political importance. One of the frequently cited works from the perspective of political communication has even announced the crisis of public communication (Blumler \& Gurevitch 1995). Other vain of thinking is that the new conventions of the public and the private challenges the idea of the rationally functioning citizen and bring about new definitions of the political and possibilities of bringing the formerly private into the public realms. Some authors have even claimed that the kind of politics that truly counts is formulated and acted upon in the private sphere and everyday life; and that such politics are fuelled best if not solely by popular culture which evokes resistance against the official hegemony or 'power-blocks' (e.g., Fiske 1989). Whether either of these views is accurate is one question, but they 
highlight the notion that the Habermasian public sphere need further consideration also in the definition of what is meant and desired for by the term public.

\section{Exclusive Public Sphere?}

Related to the need for updating the notions of the public and the private is the more specific assessment, made by many scholars in the 1990s, that Habermas remains insensitive to the dynamics of gender or other struggles of subordinate social groups. This vain of thinking finds ground both in critical theory and in cultural studies. Notably, feminist political scientists such as Nancy Fraser (e.g., 1991) and media scholars such as Lisa McLaughlin (1998) and Annabelle Sreberny-Mohammadi and Liesbet van Zoonen (1999) have emphasised the patriarchal nature of the inspiration of the model, the bourgeois public sphere, which excluded women from its scope of citizenry. This is certainly true for many other social groups and movements, and this is why Habermas has been accused of élitisim. The feminist critique, however, relates to the discussion on tabloidization debate of e.g., personalization of traditional politics and intimization of journalism (van Zoonen 1991) as it recognises the rigid separation of public and private spheres, embedded in the Habermas' ideal, that emphasises the traditionally gendered division of those spheres.

This critique, reflecting a strand of academic work that flourished in the last decade, can be elaborated by paying attention to the emergence of new kind of civic activism, for instance in the form of loose networks and single-issue movements (Dahlgren 2005, 413). The idea of a public sphere, provided by one medium (or even by several media in unison), fostering one kind of civic culture, is clearly outdated alone because of the factual reality of ever fragmenting media audiences, of different kinds of contents within one medium and different needs to follow different kinds of contents, and of the different uses of old and new media. So while for example television is not dead, it certainly cannot be said to cater for the public sphere, for everyone simultaneously. 
There is a clear connection between the public sphere theorization and public service broadcasting. On one hand, this is a paradox, as Habermas' model seems to advocate a neutral sphere that defies both the corporate and state control. From a slightly different angle, one of the model's strengths can be found precisely in that it escapes the trap of the traditional opposition of free markets versus state-governed media. On the other hand, the normative nature of the model seems to translate well into media policy practices and debates and to adjust to the mission of public service broadcasting (See account of discussion, e.g., in Collins 2002).

Undeniably, Habermas has been used to discuss the public service broadcasting mission and for its defence, against deregulatory and commercialising tendencies in practice. Concerning European media policies, a persistent (if latent) sense of the need to construct a public sphere has guided many public service media organisations (e.g., Dahgren 1995; Preston 2001; Steemers 1998). Deregulation has in the past years changed rhetorics of media policies in the EU level towards consumer-oriented discussion, and a similar trend can be seen in Finland, for instance regarding digitalization (Aslama 2003): The ideals of the free market and consumer's choice are present in the public rhetoric of the Ministry of Traffic and Communications and similarly, the directors of Finland's public service broadcasting company YLE tend in the new millennium refer to audiences as consumers. Still, the ideals of the public sphere are present, for instance, in many aspects of the law on YLE, such as the ideals of free access to all citizens, and the like. This discussion is naturally linked to the claims of crisis of public communication involving aggressive public relations and tyranny of the media as well as decline of journalism - that threatens many liberal democracies (e.g., Blumer \& Gurevitch 1995). Similar vain of thought has also been expressed regarding globalizing media markets: Rich media seems to result in poor democracy (e.g., McChesney 1999).

\section{Controversy and the Political}

When controversial issues regarding media contents such as 'trash television' or 'entertainization of TV culture' are addressed in the academic and/or public discussion, they are often presented together with the above mentioned trends. For this reason I argue that in addressing popular media culture, the public sphere paradigm and the post 
modern cultural theory have meetings points in searching for articulations of the political. Or, as Kevin Glynn explains his motivation to study tabloid culture:

\begin{abstract}
"Wherever the cultural tastes and practices of some people disgust and offend others, there can be little doubt that we are in the presence of the political... The production of disgust, offence, and popular pleasures is of primary significance for cultural theory because it is central to the general process whereby the meanings we make ourselves and of the social world are organised and reorganised. This process has crucial implications for social change, not least because it shapes the production, diffusion and urgency of the recognition of a need for change.” (Glynn 2000, 9.)
\end{abstract}

In other words, if politics is about different (social) interests for which solutions are sought, the public sphere paradigm and the (some forms of) cultural theory seem to agree in the basic assumptions and goals. In this light, it could be argued that the public sphere constructed by debate and discussion is not necessarily oppositional to discursively constructed realities, a stand point advocated in post-modern theorisation. As Fraser (1991) argues, Habermas' public sphere can be seen as:

" $[\mathrm{A}]$ theatre in modern societies in which political participation is enacted through the medium of talk ... a space in which citizens deliberate their common affairs, and hence an institutionalised arena of discursive interaction" (110).

Thus, it is symptomatic that the public sphere framework has been recognized and even utilised alongside the cultural studies oriented readings on tabloid television and tabloid journalism in general (e.g., Dahlgren \& Sparks 1992, Langer 1999, Livingstone \& Lunt 1994, Sparks \& Tulloch 2000).

In sum, the thematic of the public sphere as theoretical inspiration or scaffolding for understanding today's television is relevant for several reasons. First, the academic and public debate on changes in the television landscape can traced to the public sphere ideal. I argue that the public sphere model is an interesting starting point especially when examining European television systems that are based on a strong public service and 
hence public sphere ethos, but relevant also in any case with nation-bound television. Lastly, Habermas' model provides not only a theory but a normative stand. Sonia Livingstone and Peter Lunt (1994) who have used the public sphere paradigm when examining a form of tabloid television, that of talk shows, aptly articulate the promise that just may have caused Habermas' appeal to a variety of theoretical and empirical applications in the past decades:

"Habermas' position reflects the ambivalence felt by many towards the mass media - that there is a great power, but can it be harnessed for the public good? We suggest that pessimistic answers tend to underestimate the complex and contradictory or fragmented nature of the contemporary mass media which opens the way for some escape from institutional control, while more optimistic positions often set too high ideals for the public sphere. Those alternative formulations of the public sphere which recognize and build on the complex and fragmentary nature of the media suggest more positively that the media could facilitate and legitimize the public negotiation - through compromise rather than consensus - of meanings among oppositional and marginalized groups.” (1994, 10-11)

\section{Re-Modelling the Public Sphere: The Case of Television}

One of the most elaborate adaptations by media scholars of the Habermasian public sphere for a specific thematic is Peter Dahlgren's book Television and the Public Sphere. Citizenship, Democracy and the Media (1995), recently refined by his update article Television, Public Spheres and Civic Cultures (2005). Dahlgren addresses the public sphere idea in the context of television by integrating its various readings and critique, by crystallizing main themes and questions that thus arise, and by mapping the issues under the categories of (1) social structures; (3) media institutions; (3) sociocultural interaction; and (4) media representations. Through this discussion, Dahlgren thus comes up with a conceptual framework, in which 
"[e]ach dimension serves as an entry port to sets of issues about the public sphere, both theoretical and conceptual questions as well as empirical and evaluative ones about its actual functioning $(1995,11)$.

I find Dahlgren's basic approach useful as it provides a structured way to theorise as well as empirically analyse the public sphere. Arguably, as Dahlgren notes, the four dimensions are closely intertwined and condition each other $(1995,11)$; yet, the framework makes it possible to conduct focused and systematic empirical analysis on a specific dimension. Yet another strength of Dahlgren's reworking of the public sphere concept is his update (2005), in which he takes into account of the developments of the past decade. He notes that the technological developments lead to technological convergence between television as we know it and other media, but even more importantly, he argues for integration of television and other forms of media culture. $\mathrm{He}$ also brings forth the idea of multiple public spheres and emphasizes the increasingly blurring boundaries of the public and the private. He recognizes the importance of popular culture in television and advocates utilization and combination of the 'culturalists' (Dahlgren's term for cultural studies oriented) perspectives with the more traditional social sciences oriented views to the thematics television and the public sphere; this is a parallel to his ideas of interlinking political science, public sphere and culturalist approaches (Dahlgren 2004).

However, Dahlgren's (2005) most interesting elaboration - at least regarding the linkage between empirical analyses and a broader perspective of the relevance on television culture - is that instead of concentrating on citizenship (as in 1995) he stresses the notion of civic cultures. He re-emphasises the fact that television's role is not only to provide a sphere for expressing such cultures, but also in pre-structuring them. He also lays out a conceptual model of five dimensions of civic cultures: (1) knowledge and competence, (2) values; (3) affinity and trust; (4) practices; and (5) identities. They can, according to Dahlgren, be seen 'as integrated circuits with five mutually reciprocal dimensions' and that can be taken 'as starting points for empirical inquiry about the media's significance for civic cultures, and (...) on the role of television' (Dahlgren 2005, 424). 
Dahlgren $(1995,11-23)$ defines the four basic dimensions of the public sphere as follows (see also Figure 1):

1) Social structures. Dahlgren formulates this category constituting of institutional arrangements of society, including social stratification, power alignments, and the state. Thus, it entails political, economic and legal aspects, as well as, for instance, the nature and quality of educational system. Dahlgren admits that this dimension is potentially so broad that at some point of the analysis it must 'be put in brackets', in order to be able to remain the focus in the public sphere (op cit. 12). However, he strongly emphasises Habermas' point of the public sphere as historical, connected to and constructed by larger social figurations. Therefore, although social structures can be said to constitute and condition the other aspects of the public sphere - in his words, institutions, interaction and representations - it is important to recognize this overall dimension. In this context, Dahlgren raises an issue that reflects to the complex conditions of today's societies and that he calls 'the tension between the whole and the parts' $(1995,18)$ : should there be a single (if pluralistic) public sphere or can many spheres together constitute one?

2) Media institutions. By this, Dahlgren refers to the organization, financing and legal aspects - from those governing ownership and control to those pertaining to constrains and freedoms of communication. He brings up the issue of (national) public service broadcasting in the commercialising and globalizing television markets as one of the central themes of this dimension.

3) Sociocultural interaction. This dimension 'refers to non-mediated face-to-face encounters between citizens, to relevant aspects of subjectivity and identity processes and to the interface of media and citizens' (op cit. 12). Dahlgren sees the last point, that is, processes related to media reception, being often the first step of interaction and notes:

“[T] he public sphere is not just a 'marketplace of ideas' or an 'information exchange depot', but also a major societal mechanism for 
the production and circulation of culture, which frames and gives meaning to our identities." $(1995,23)$.

Accordingly, the question of interest in this dimension is if and how people's identities as citizens and / or consumers are constructed.

4) Media contents. Dahlgren uses the term media representation, and defines it as concerning what is portrayed, how topics are presented, what modes of discourse are at work and what the character of debates and discussions are. However, I suggest the term media contents, as it can then include television output both with very broad, overall quantitative terms, while also addressing specific 'representations'. Dahlgren notes that this dimension simply points to the fundamental questions: What should be selected for portrayal and how should it be portrayed? This dimension, then, calls for monitoring of the media, for critical analyses of infinitive perspectives.

The internal dynamics between the various dimensions of this public sphere model, although not explicitly discussed by Dahlgren (1995), are sketched in figure 1 . The figure is intended to illustrate the encompassing nature of social structures that shape institutions, social interaction as well as contents. This is surely a two-way dynamics, but the 'feedback' from the three is not as overt or pronounced. With the figure, I also suggest the self-evident notion that media contents are central to the idea of television as a public sphere. Similarly, as darker and lighter arrows indicate, institutional setting (e.g., whether a broadcaster is a public service or commercial one) tends to influence, in general terms, contents more strongly than vice versa. The dynamics between media contents and social interaction should and could ultimately be free flowing, media output fostering interaction and interaction feeding into media contents. The basic 'dumbing down' argument seems to insinuate that this relationship does not work sufficiently well from the contents to interaction and thus democracy is not fostered; and the critique of the public sphere model reminds us of the fact that the opposite flow is often very homogenous, that is, the multitude of possible voices are not reflected in the contents. 
Figure 1. Four Dimensions of Television as a Public Sphere

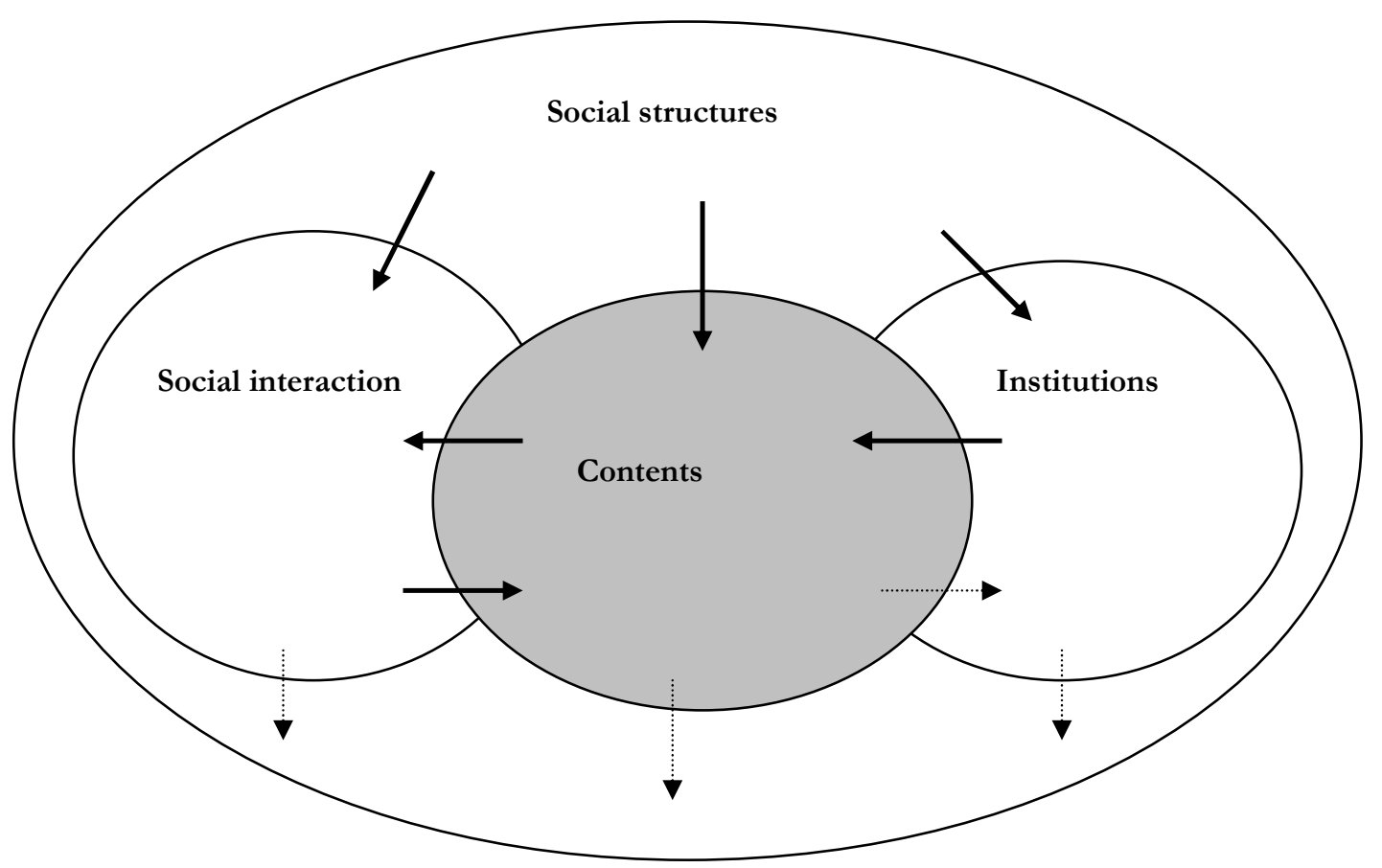

Source: Modified from Dahlgren 1995

Dahlgren's (1995) model, in sum, raises several issues. One pertains to the question to what extent television in fact can constitute a public sphere in today's diverse societies. More elaborately, in Dahlgren's words: What is the relationship between the rational/analytic versus affective/aesthetic modes of communication, and can the typical analytical connection between politics and rationality versus entertainment and emotionality be contested? Dahlgren recognises the value of Habermas' theorisation of the public sphere, but argues that by no means it is a concept that should remain unchanged. He positions the public sphere as a historically contingent, negotiated and contested space that is constructed also in the 'discursive practices of civil society' (1995, 23). Furthermore, Dahlgren's four dimensional model (1995) recognises the political economy aspects and commercial imperatives of television, as well as viewers' various positions, but neither glorifies popular culture nor emphasises any normative evaluations. Instead, he points out particular features of television (journalism) that defy the traditional binary divide of 'public knowledge' and 'popular culture'. Thus, Dahlgren's 
framework allows for an approach that can be distanced from the often value-laden commentary based on traditional opposites. At the same time, this framework invites and requires discussion on the extent, potential and fluidity of television's role as a public sphere - or, for instance, the possible existence of a 'popular' or 'oppositional' public sphere (Livingstone \& Lunt 1994; Sreberny-Mohammadi \& van Zoonen 1999) - as, according to Dahlgren,

\footnotetext{
"Television operates in this late modern setting as an industry, as an incessant producer of audio-visual discourses which have a central position in the semiotic environment. As an industry, television has to follow the precepts of audience maximization and profits; moreover, it is the paramount vehicle of consumer culture. While television is the dominant medium of the public sphere, 'public sphering' is clearly not television's dominant purpose, and its institutional logic greatly conditions its role within the public sphere. As a sociocultural experience, television provides symbolic 'raw materials' which are experienced and reflected upon in varying degrees." $(1995,148)$
}

\section{Specifying Public Spheres: Fluidity and Plurality}

Dahlgren's (1995) four-dimensional public sphere model as such provides for a theoretical framework. However, I further specify it by two thematic notions that, although addressed by Dahlgren (in both 1995 and 2005), I argue deserve further emphasis in the context of today's television and today's (western) societies. The concepts are here labelled as fluidity and plurality.

\section{Fluid Boundaries of the Public Sphere}

The first specification to Dahlgren's public sphere model concerns the definitions of the boundaries of the public spheres and television's historical position. To address some of the changes for a pluralist, descriptive, non-normative framework for television's potential in the formation of one or more public spheres, I add an attribute to Dahlgren's 
model that deals with recent theorising of changes in overall societal conditions, the public sphere in relation to other societal spheres, and main changes regarding television as a medium. I borrow the basic term 'fluid' from Zygmunt Bauman's work on Liquid Modernity (2000).

While considered as a key theorist of postmodernism, Bauman seems to imply in his recent work that we live in a world in which some characteristics are still fundamentally modern, yet some are in a process of constant change. Therefore, with the term 'fluidity', I wish to describe the present social conditions that in my view surround television's role as a potential public sphere. In Bauman's latest writings, he has indeed replaced the term postmodern with the idea of modernity as liquid or fluid. With this shift, he seeks to emphasise that we are not past modernity, but in a transitional stage where old characteristics of the society mix with the new. 'Fluid' as a metaphor, then, refers to a situation where society's key modern characteristics - the pursue for stability and permanence that equal safety - have faded. Instead, we are heading towards a society dominated by insecurity, unsafety, and uncertainty. These, in turn, are caused by ever changing, liquid state of affairs. The central features of such a society are, for instance, the importance of time (as everything is only of momentary character); the mobilization of power that becomes more and more slippery, and harder to track down; and the disintegration of social networks. The disintegration means disengagement from common frames of reference and any kind of dependence - for example, the growth of differentiation and individualization, and as a result, the disappearance of traditional Politics 'with a capital P' (e.g., Bauman 2000, 39). Instead, people engage in individual life politics that concentrate on a lonely life of achieving and consuming.

In this context, Bauman addresses the media, television in particular and claims that the public space or sphere (terms used in his work synonymously) is becoming empty. This is not an original idea as such but seems to be in line with the main strand of the tabloidization discussion. However, Bauman $(2000,70)$ argues that this shift is not abstractly caused by the Zeitgeist of the times, but is a result of a fundamental transformation of the public sphere. He gives it a new provocative definition: 'public space is where public confession of private secrets and intimacies is made' (op cit., 40). Yet, he does not remain with the criticism of consumerism and entertainment- 
orientation. Bauman sees a more fundamental meaning in the lightening of media output. He claims that the question is not about the ever shifting boundary between what is private and what is public, but that in the public sphere, citizenship-based politics have been replaced with public display of private affairs. The media, then, do not act accordingly only out of, for instance, commercial imperative to entertain, but they, television in particular, feed into a specific need of the liquid society. The media provide individual solutions to shared problems: they create momentary spectacles so that people can pretend they belong, and that they can see how other lonely individuals cope with individual problems of life politics:

\footnotetext{
"Each day the first-page press and first-minute TV headlines wave a new banner under which to gather and march (virtual) shoulder to (virtual) shoulder. They offer a virtual 'common purpose' around which virtual communities may entwine ... [T] hey effectively ward off the condensation of 'genuine' (that is, comprehensive and ever lasting) communities which they mime ...They scatter instead of condense the untapped energy of sociality impulses and so contribute to the perpetuation of the solitude..." (op cit., 201).
}

In addition to the strong criticism on the media of the 'liquid modernity', Bauman also has a solution in the form of a strong view on the notion of the public sphere. In his view, the societies defined by the 'unholy trinity' of uncertainty, insecurity and unsafety require joint action and some forms of consensus (even at a global level) instead of individual discursive identity construction and private resistance of the power-block through consumption:

\footnotetext{
"Any true liberation calls today for more, not less, of the public sphere and public power. It is now the public sphere which badly needs defence against the invading private - though, paradoxically, in order to enhance, not cut down, individual liberty" (op cit. 51).
}

By utilizing the concept 'liquid modernity' as a metaphor surrounding the social structures as well as other dimensions of the public sphere, I seek to clarify following theoretical issues: First, Bauman's argumentation helps to refuse the term of 
postmodernism and as characterising the social conditions of today. While I see much of the postmodern mode of media theorising useful, especially regarding popular television culture, my choice of the public sphere paradigm points to another basis of the study. Accordingly, I agree with Preston's $(2001,98)$ interpretation on Habermas' opposition on postmodern theorising in reference to both techno-utopian rhetoric regarding media technologies as well as to the most optimistic strands of cultural studies referring to everresisting active audiences. Both views seem to carry features of neoliberal thinking that advocates separation of common, traditional politics from moral-practical justification. Also, while Bauman denies the optimistic postmodern views on the media, he also can be interpreted to refuse the idea of complete refeudalization of the public sphere. Rather, Bauman's strong views on how privatization of the public sphere is connected to the conditions of liquid modernity re-iterate a normative presumption or an ethical basis of the public sphere model, but in the context of today's societies. Whether a local or a global scale is in question, the underlying principle of the modification of the public sphere model is that the media should participate in forming a democratic public sphere (if not many), by giving access and representing different viewpoints (or, in Dahlgren's terms, 'civic cultures'), as well as by assisting in formulating and realising society's common goals (Dahlgren 1995, 53-54).

\section{Public and Other Spheres}

Yet another consequence of emphasising the fluid nature of modernity helps to set boundaries to the public sphere as an analytical concept and to position Dahlgren's fourdimensional model of television as a public sphere in relation to other spheres in the society. By acknowledging the possibility of fluid modernity, one acknowledges rapidly changing structures the current societies and the fluidity of various boundaries. For this purpose, I find Thomas Janoski's $(1998,13)$ model of four societal spheres - the state sphere, public sphere, market sphere and private sphere - useful. In his model, the state sphere includes the executive and juridiciary powers, bureaucracy, as well as the police, military, and the like. The market sphere consists of different markets, and firms operating in those markets, as well as labour unions influencing the sphere. The private sphere is that of family and friends, of intimate relationships. 
Janoski's (1998) understanding of the public sphere, then entails voluntary associations, social movements, self-help groups, education and health care - as well as, essentially, the media. However, he emphasises the fact that the borders between the spheres are by no means fixed and strict, but that the spheres overlap. Accordingly, he positions television not only as a component of the 'pure' public sphere. One overlapping area is between the public and state spheres, in the realm in which he also positions political parties and which for him is the realm of public service broadcasting. The other area where television is present is situated in the meeting of the public and the private spheres: this occurs when people's private lives disclosed in the media.

Janoski (1998, 13-14) himself recognizes the much discussed blurring boundaries of the public and the private spheres and states that increasingly in modern times, the state, market, and the public spheres have invaded the private sphere. Another increasingly fluid border or overlap could be seen between the market, the state and the public sphere, as the economization, or the distance between the economical and the political have been said to diminish if not vanish (e.g., Preston 2001). In addition, many scholars who address the so called marketization of the media would most likely like to place for instance much of today's television in an intersection of public and market spheres. Also, while Janoski's nation-based model is relevant to the examination of television with a nation-wide focus, internationalisation and globalisation tendencies influence the spheres. Indeed, it has been argued that globalized media markets have already emerged full force, and the medium most affected is television; both regarding ownership as well as contents (McChesney 1999, 78-80). With these alterations in mind, I argue that Janoski's conceptualisation of the location of the public sphere helps to understand the dynamics and overlaps between various societal spheres.

\section{Television in the Era of Availability and Plenty}

The final additional emphasis regarding fluidity concerns a changing characteristic of television as a medium. As Dahlgren (2000) mentions, recent changes specifically influencing television in Europe include deregulation, diminishing support for public service broadcasting and a shift towards neoliberal attitudes on media's role in the society, as well as a general individualization of culture. However, I borrow a further 
theoretical notion of television's historical position, complementing Dahlgren's model, from John Ellis' work Seeing Things. Television in the Age of Uncertainty (2000). Based on above mentioned developments, and taking technological advancement into account, Ellis traces television history as having developed from the 'Era of Scarcity' and the following 'Era of Availability' to the current 'Era of Plenty'. He is inspired by Bauman's theorisation of the current social conditions and implies that the Era of Plenty coincides with the 'Age of Uncertainty', or, in other words, in the conditions of liquid modernity. Ellis (op cit., 72) argues that in the times of fragmented audiences and increasing choice of television contents, this medium can provide people with a process of 'working through' the complex nature of our liquid societies. He refers to Bauman, yet takes a more positive stand than the latter, in emphasising television's importance to the Age of Uncertainty:

"[C]old tolerance is not enough between differing beliefs and the lifestyles that accompany them. What is needed is 'sympathy', and sympathy is the product of television's process of working through. By placing explanations, rearranging the facts, looking from all possible angles, using the different emotional registers of its different genres, television is able to provide sympathy across the process of differentiation that is modern consumer society." (Op cit., 85)

The relevance of Ellis' thinking to the public sphere model used here is that television is taking increasingly different institutional forms, providing more contents with new technologies, potentially involving diverse social structures and social interaction in diverse ways in different situations - thus contributing to its fluidity as a public sphere. By the same token, as Ellis notes, the working through is an open-ended process without a conclusion, but television's power is in its ability to provide for different sense-making processes that contribute to understanding of the uncertain times of liquid modernity. Dahlgren (2005, 417-419), too, recognizes Ellis' orientation as important in theorizing television and the public sphere, and suggests three expansions to it, mirroring the idea of fluidity: First, he notes that there are multiple trajectories such as class, gender, ethnicity, but also technology as well as local, national and global settings - and they all shape working through in complex and contradictory, un-fixed ways. Second, working through is different for different kinds of groups, and thus television's 'hegemony is 
loose, leaky and always at risk' (418). Third, Dahlgren wants to emphasise that Ellis' approach is not polarized between affective and rational - in other words, working through could be said to be a fluid process between the two.

In sum, to include definitions of historical specificity that emphasise the fluid nature of television as a public sphere to Dahlgren's model, I want to 1) frame it within today's (western) world as fluid modernity, 2) locate it in shifting, overlapping relations with other societal spheres, and 3) recognise that television as a medium has entered the Era of Plenty that may contribute to the model of television as a public sphere that is changing - not towards a specific direction, but fluidly.

\section{Plurality, Viewers' Positions and Civic Cultures}

The second specifying concept to Dahlgren's (1995) model of the public sphere, plurality, is indeed recognised by him. Yet, I discuss the concept further, as it is at the core of Dahlgren's reworking of the public sphere thematic (2005), and as it has been widely discussed in relation to the classic Habermasian public sphere in many contexts. I find it paramount to overcome the dual definition of the position of the viewer as viewercitizen (as it is central in the original Habermasian public sphere framework) and the viewer-consumer (as the view is emphasised by the postmodern cultural theory-based of research) (e.g., Livingstone \& Lunt 1994, 18-19). This, in turn, leads to the fundamental re-definition of the public sphere idea as containing plurality in itself, and specifically, to the view that television, in Dahlgren's (2005) terms, fosters civic cultures - in plural.

At the outset, based on my reading of Dahlgren's (1995) four-dimensional public sphere model, I define mass communication, including television, as mediated communication that potentially reaches mass audiences. Yet, as many theories as well as empirical evidence have proven, the masses are in today's communicative context seldom reached; instead, current overview in the European situation reiterates the 'fragmentation' or 'polarization' of television views as relatively fluid groups of audiences (Schutz 2000). This means that viewers seem to form all smaller subgroups or, in business terms, 'audience segments', or the viewers divide as audiences of certain few genres. Also, an 
audience consisting of a group of viewers is not synonymous to a public. In contrast to the term 'public' as accessible to all, used for instance in the case of public service broadcasting, Habermas $(1962 / 1989,2)$ notes that the most commonly used meaning of 'the public' refers to the public carrier of public opinion as a 'critical judge' to counter official powers. Admittedly, public service broadcasting ethos often seems to imply that the condition of an institution being 'public' best serves the formation of 'a public' of 'the public'. Based on Dahlgren's (1995) theorizing, I see the concept of 'a public' as a 'critical judge' as a potential, neither a normative ideal nor a descriptive analytical tool.

Furthermore, the concept of television viewers as citizens has undeniably been at the core in thinking inspired by the public sphere paradigm. The citizen entails the modernist idea of 'passive and active membership of individuals in a nation-state with certain rights and obligations' (Janoski 1998, 9). In contrast, as already mentioned, (postmodernist) cultural theory has often been considered to address the viewer as a consumer, if an actively resistant and reflective one. Toby Miller $(1999,282)$ states, somewhat ironically, that when discussing television, there still exists a complicated relationship between citizen and consumer, 'even though the citizen is a wizened figure from the past and the consumer is a naïve phenomenon, essentially a creature of the nineteenth century'.

However, Dahlgren's model $(1995,2005)$ clearly indicates that television may provide positions of the citizen or the consumer in different times, or combine them. Even further, television audiences may be offered positions beyond the dichotomies, such as the participant or the player, as for example Trine Syvertsen (2004) suggests. Indeed, there seem to be competing conceptions both in the academic discourses as well as on public discussion on public communication and the kinds of collective groups it forms, summarized and labeled aptly by Paschal Preston's $(2001,244)$ as Civic National, Affective National, Postmodern Cultural and Global Information. The Civic National idea is based on citizenship, and here, in a true Habermasian fashion, identity means rational, critical members of a political community that collectively form a public sphere. Affective National, in contrast, is according to Preston's model a combination of a political identity and particular cultural or ethnic identities. These various identities take distinct national and other civic and social formations. The key actors, in this view, are citizens and bearers of a distinctive cultural or expressive identity. In contrast, the 
predominant identities of the postmodernist cultural view are that of active audiences, in a situation where national and other modern social identities have collapsed. These identities, then, are individual and multiple, and the key actors are active audiences or reflexive consumers; sometimes defined as 'socially situated' audiences. Finally, the global information society view (in its neo-liberal version) sees the key actors of public communication simply as consumers of media products in the market-place.

Surely, as Preston (2001) emphasizes, the above are abstract analytical categories that will be combined in many 'discursive accounts and practices'. But exactly as such they highlight that in the blurring world of the public and the private, citizenship is perhaps no longer the sole sufficient concept, even when theorization stems from the public sphere tradition. Plurality is at stake here, too. Also, television viewers do not engage a systematic and static use of television as a public sphere, and while the critical-rational citizen may be the key participant in a democracy, it may not be the only or the 'pure' position for participating in a public sphere. For example Ellis (2000) uses the concept of witness; and in my view his idea implies that shared witnessing and 'working through' with television may be a part of a public sphere, alongside with more active and explicitly rational debate and opinion formation.

However, I want to emphasize that I do not wish to replicate what Preston (2001) calls the 'Postmodernist Cultural' stand, in that the existence of 'modernist identities' would be denied and that the communal, shared, unifying elements of public communication for the traditionally political would not be recognized. This simply implies that televised public communication is not for citizen-viewers or consumer-viewers only. By buying into one particular conception would mean to undermine the pluralist nature of the medium. As Dahlgren (1995) states:

"Television fragments and unites, it clarifies and occludes, it informs and distracts. (...) In terms of television's role in the public sphere, we would be foolish to exaggerate its contribution to critical reason and progressive affect (...) 
Dahlgren (2005) has taken this exact issue as one of his main revisions of his public sphere model and defines his view on citizenship in today's societies through the notion of political agency, as one mode of individual and collective action. Therefore, he emphasize the idea of identity formation (citizenship being one identity or rather, a part of an identity of an individual) and then goes on launching the notion of civic cultures, 'as referring schematically to those cultural patterns in which identities of citizenship, and the foundations of civic action, are embedded' (422). He parallels civic cultures to Putnam's (2000) idea of 'social capital' in that civic cultures are resources for individuals and groups when they act as citizens (Dahlgren 2005, 423).

In further mapping such resources and television's role in enhancing the resources, Dahlgren $(2005,424-430)$ openly declares his pluralistic view in the theoretical realm. He wishes to overcome the main flaws and utilize the main strengths of three traditions. Thus, he not only draws from the public sphere perspective but couples it with political science - in order to keep the formal democratic politics in the picture. In addition, he turns to culturalist approaches that help in understanding of processes of the production of meanings. With these tools at hand, he constructs the five circuits of civic cultures that, while integrated, can 'be individually thematized and studies in empirical cases' (424). The dimensions and their relation to the public sphere disposition are summarized below (see also figure 2):

1) Knowledge and competence. With this circuit, Dahlgren stresses the current existence of multiple, fragmented public spheres that possess different knowledge and competencies; but also the problematic nature of such a situation for a functioning democracy.

2) Values. While Dahlgren notes that values enhancing democracy can be disputed, he clearly points out the possibility of the media (television), as 'civic cultures need to underscore commitment to both rules of the game [procedural values of a democracy] and the larger visions of a democratic society' (426).

3) Affinity and trust. In Dahlgren's words, affinity and trust point out to the need for 'a minimal sense of commonality among citizens in heterogeneous late modern societies'. 
4) Practices. This circuit deals with the notion that a democracy is built on and functions because of certain practices, discussion and rational decision-making being the traditional practices connected to the public sphere ideal. Dahlgren extends this circuit also to entail, e.g., practices of television viewing - that may be said to relate to individual control and empowerment.

5) Identities. This circuit is explicitly concerned with the identity formation of the viewers, and the ways they are addressed. While citizen is not the only identity, it is still needed to foster a democracy. Thus, citizenship in turn still needs to be fostered for example by the media.

To condense the model, Dahlgren's (2005) five dimensions of civic cultures, although thematically distinct, clearly intertwine. Each of them can be supported, renewed and reworked in a mediated public sphere, and they, in turn, provide resources for citizenship. 
Figure 2. Circuits of Civic Cultures

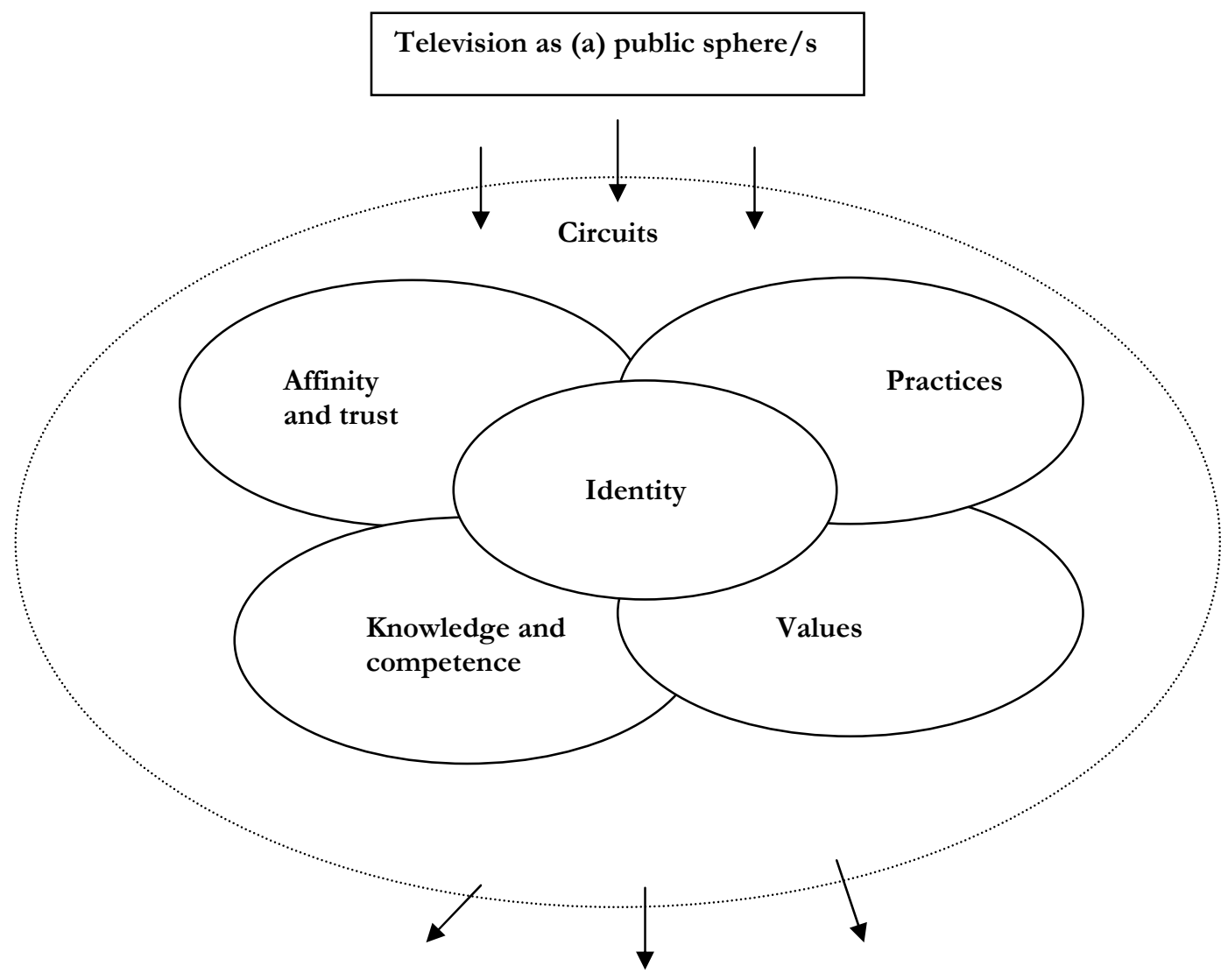

Activities as citizens

Source: Modified from Dahlgren 2005

Television as a 'Platform' for Plural Public Spheres

The final emphasis I wish to add to Dahlgren's model stands close to the discussion of the position of the viewer, namely the possible plurality of spheres. This is often seen to emerge regarding forms of and communicative modes offered by popular culture, for example tabloid television. Based on their work on talk shows, Livingstone and Lunt (1994) argue that the elitist, state-governed broadcasting as well as the market-driven commercial broadcasting both disregard the participatory aspect but, in concrete terms, 'a]s more ordinary people participate in making television programmes such as talk shows as well as receiving them, this gives new force to the concept of the active viewer' (19). In their view, this creates alternative spheres next to, or opposed to, the traditional public sphere. Underlying here is the fundamental debate regarding the framework of the 
public sphere that Livingstone \& Lunt (1994, 94-95) have articulated as follows: Habermas proposes for the institutional development of a critical voice within the lifeworld so as to produce a consensual and reasoned challenge to established power, whereas proponenets of the oppositional public sphere, often drawing from the cultural studies tradition, view institution as a context for diverse voices with different power bases. My reading of Dahlgren's $(1995,2005)$ theorization makes it possible to consider that in this framework, amongst other components of a public sphere, television provides a particular platform for multiple spheres. What positions they take and in which kind of sense-making, consuming or will-formation processes they engage is not only their choice as individuals forming active audiences.

What is left from the original Habermasian public sphere concept, if I recognize the fluidity, plurality and heterogeneity as well as the limited potential of television as a public sphere? Again, by emphasizing the possibility of multiple, plural and changing public spheres, I do not mean to, for example, transform the public sphere framework into some 'poststructurally inflected version of hegemony theory' - as Glynn (2000) notes when critically assessing Livingstone \& Lunt's (1994) revisionist terms of 'proletarian' and 'oppositional' public spheres in relation to tabloid television. What I have sought to stress is that change is not ahistorical, that nation-state bound, public service oriented broadcasting is still alive in Europe, but that the current social context also has elements of fluidity and plurality.

The possible existence of multiple public spheres is not a novelty but has been given importance when theorizing politics in relation to formation of 'new communities' and the new media (e.g., Preston 2001, 208-209,). They form a plural and decentered public sphere constituted not by total identification as in the traditional community - for example, that of a nation-state - but rather by conflict, combining notions of interest and identity. It is characterized by the overlapping of an array of institutions and practical formations, including informal movements and associations where solidarities are formed, as well as formal governmental and legal institutions. Next to techno-utopian visions, it has namely been questioned if people's ability to create their own Net-based communities actually allows them to ignore other communities and 'bypass any contact with the balance of society' (McChesney 1999, 146). 
Thus, I suggest, following Ellis (2000) that television, specifically, can bear a plurality of roles, as the core aspect of broadcast television has historically been 'to provide a voluntary point of social cohesion, of being together while being apart'; thus, it differs from 'most of the models of interactivity and choice [which] imply a lone consumer making choices in isolation' (op cit.: 176-77). As I have argued elsewhere (Himmelstein \& Aslama 2003), this vain of theorizing need not to be restricted to the Internet, but could and should be conceptualized especially regarding television. Peter Dahlgren's work provides intellectual scaffolding for such efforts. 


\section{References:}

Aslama, Minna (2003)

Digikansalainen kadoksissa? Katsojien roolit digitaalitelevisiosta käydyssä keskustelussa.

Teoksessa Malmelin, N. (toim.) Välittämisen tiede. Viestinnän näkökulmia yhteiskuntaan, kulttuuriin ja kansalaisuuteen. Ullamaija Kivikurun juhlakirja. Viestinnän julkaisuja 8. Helsinki: Helsingin yliopiston viestinnän laitos. [On digitalization debate in Finland]

Bauman, Zygmunt (2000)

Liquid Modernity. Cambridge: Polity Press.

Blumler, Jay \& Michael Gurevitch (1995)

The Crisis of Public Communication, New York: Routledge.

Collins, Richard (2002)

Media and Identity in Contemporary Europe. Consequences of Global Convergence. Bristol: Intellect Books.

Dahlgren, Peter (1995)

Television and the Public Sphere. Citizenship, Democracy and the Media. London, Thousand Oaks \& New Delhi: Sage.

Dahlgren, Peter (2000)

Key trends in European Television. 23-34. In Wieten, Jan, Murdock, Graham \& Peter Dahlgren (eds.). Television Across Europe. A comparative Introduction. London, Thousand Oaks \& New Delhi: Sage.

Dahlgren, Peter (2004)

Theory, Boundaries and Political Communication. European Journal of Communication Vol19(1): 7-18.

Dahlgren, Peter (2005)

Television, Public Spheres and Civic Cultures. In Wasko, Janet (ed.). A Companion to Television. 411-432.

Dahlgren, Peter \& Sparks, Colin (1992) (eds.)

Journalism and Popular Culture. London, Thousand Oaks and New Delhi: Sage.

Ellis, John (2000)

Seeing Things. Television in the Age of Uncertainty. London \& New York: Tauris.

Fiske, John (1989)

Understanding Popular Culture. London \& New York: Routledge.

Fraser, Nancy (1991)

Rethinking the Public Sphere: A Contribution to the Critique of Actually Existing Democracy. In Calhoun, Craig (ed.). Habermas and the Public Sphere. Cambridge, MA: MIT Press. 109-142.

Glynn, Kevin (2000)

Tabloid Culture. Trash Taste, Popular Power and the Transformation of American Television.

Durham and London: Duke University Press.

Habermas, Jürgen (1989/1962)

Structural Transformation of the Public Sphere. Cambridge: Polity Press. 
Habermas, Jürgen (1996)

The Inclusion of the Other. Cambridge, MA: The MIT Press.

Himmelstein Hal \& Aslama, Minna (2003)

From Service to Access. Re-conceiving Public Television's Role in the New Media Era. In Lowe G.F. \& Hujanen, T (eds.). Gothenburg: RIPE/NORDICOM.

Janoski, Thomas (1998)

Citizenship and Civil Society. A Framework in Liberal, Traditional and Social Democratic

Regimes. Cambridge \& New York: Cambridge University Press.

Langer, John (1998)

Tabloid Television. Popular Journalism and the 'Other News'. London \& New York: Routledge.

Livingstone, Sonia \& Peter Lunt (1994)

Talk on Television. Audience Participation and the Public Debate. London \& New York:

Routledge.

McChesney, Robert (1999)

Rich Media, Poor Democracy. New York: The New Press.

McLaughlin, Lisa (1998)

Gender, Privacy and Publicity. In Carter, Cynthia et al. (eds.). Gender, News and Power. London: Routledge.

Miller, Toby (1999)

Television and Citizenship: A New International Division of Cultural Labor? In Calabrese, Andrew \& Jean-Claude Burgelman. Communication, Citizenship, and Social Policy. Rethinking the Limits of the Welfare State. Rowman \& Littlefield Publishers, Inc. Lanham, Boulder, New York, Oxford. 279-292.

Preston, Paschal (2001)

Reshaping Communications. Technology, Information and Social Change. London, Thousand Oaks \& New Delhi: Sage.

Putnam, Robert (2000)

Bowling Alone: The Collapse and Revival of American Community. New York: Simon \& Schuster.

Schulz, Winfried (2000)

Television Audiences. In Wieten, Jan ym. (eds.) Television Across Europe. London, Thousand Oaks and New Delhi: Sage, 113-134.

Sparks, Colin \& John Tulloch (2000)

Tabloid Tales. Global debates over media standards. Lanham, Boulder, New York \& Oxford: Rowman \& Littlefield Publishers, Inc.

Sreberny, Annabelle \& van Zoonen, Liesbet eds. (1999)

Gender, Politics and Communication, New York: Hampton Press.

Steemers, Jeanette (1998)

On the Treshold of the 'Digital Age'. Prospects for Public Service Broadcasting. In Steemers, Jeanette (ed.). Changing Channels. The Prospects for Television in a Digital World. 97-123. Luton: University of Luton Press. 
Syvertsen, Trine (2004)

Citizens, audiences, customers and players. European Journal of Cultural Studies, Vol 7(3): 363380.

Thompson, John B. (1990)

The Media and Modernity. A Social Theory of the Media. Stanford University Press.

Van Zoonen, Liesbet (1991)

A Tyranny of Intimacy? Women, Femininity and Television News. 217-235. In Dahlgren, Peter \& Colin Sparks (eds.) Communication and Citizenship. London: Sage. 